\title{
Evaluation of the Corrosion of AZ31 Magnesium Alloy Used as Sacrificial Anode for Cathodic Protection of Hot-Water Tank Storage Containing Chloride
}

\author{
N. Zidane ${ }^{1}$, Y. Ait Albrimi ${ }^{1}$, A. Ait Addi ${ }^{1}$, J. Douch ${ }^{1}$, R.M. Souto ${ }^{2,3, *}$, M. Hamdani $^{1, *}$ \\ ${ }^{1}$ Laboratoire d'Electrochimie, Catalyse et Environnement, Faculté des Sciences, Université Ibn Zohr, \\ Agadir, Maroc. \\ ${ }^{2}$ Department of Chemistry, Universidad de La Laguna, La Laguna (Tenerife), Spain. \\ ${ }^{3}$ Institute of Material Science and Nanotechnology, Universidad de La Laguna, La Laguna (Tenerife), \\ Spain. \\ *E-mail: rsouto@ull.es, hamdani.mohamed@gmail.com
}

doi: $10.20964 / 2018.01 .36$

Received: 3 July 2017 / Accepted: 19 September 2017 / Online Published: 1 December 2017

Corrosion resistance of AZ31 magnesium alloy was evaluated in aqueous chloride-containing solutions. Combined weight loss and electrochemical data indicate that corrosion rate of magnesium alloy increased for greater $\mathrm{NaCl}$ concentrations and higher temperatures. Corrosion is characterized by the formation of precipitates, that present the distinctive XRD patterns corresponding to crystalline phases of $\mathrm{Mg}(\mathrm{OH})_{2}$, accompanied by $\mathrm{H}_{2}$ evolution, these processes leading to $\mathrm{pH}$ increases in the solution. Retrieved samples show a film of corrosion products distributed around cracks on the bare metal surface, and the subsequent development of large pits that prevent the material from attaining passive protection.

Keywords: Corrosion; Cathodic protection; Sacrificial anode; Magnesium alloy AZ31; Potentiodynamic polarization; Electrochemical impedance spectroscopy.

\section{$\underline{\text { FULL TEXT }}$}

(C) 2018 The Authors. Published by ESG (www.electrochemsci.org). This article is an open access article distributed under the terms and conditions of the Creative Commons Attribution license (http://creativecommons.org/licenses/by/4.0/). 